\title{
'The Wife Would Put on a Nice Suit, Hat, and Possibly Gloves': The Misogynistic Identity Politics of Anders Behring Breivik
}

\author{
Fredrik Wilhelmsen \\ Faculty of Social Sciences, Nord university, Bodø, Norway \\ wilhelmsen.fredrik@gmail.com
}

\begin{abstract}
By analysing the anti-feminist and misogynistic narratives in Anders Behring Breivik's compendium 2083: A European Declaration of Independence, this article argues that Breivik's counterjihadist worldview can be located both as a permutation of 'generic fascism' and as a form of nonegalitarian 'identity politics'. First, the article reframes and reformulates Nancy Fraser's concept of identity politics, as it sets Breivik's ideology in relation to her theory of a 'politics of recognition', arguing that her theories originally developed to analyse left-wing politics - can be used to identify how questions of identity are at the centre of the dynamics of Breivik's far-right ideology. The article then goes on to demonstrate how Breivik's misogynist narratives are plotted into a broader fascist conception of history, where the alleged feminised and Islamised present is described as an estrangement from a glorious past dominated by white, European men. As a result, Breivik's futural palingenetic vision of a 'European cultural renaissance' is not only going to resurrect a white, homogenous, 'Christian' society, but also restore patriarchy.
\end{abstract}

\section{Keywords}

Norway - counterjihadism - misogyny - identity politics - generic fascism - terrorism - Anders Behring Breivik (1979-)

'Most Europeans look back on the 1950s as a good time. Our homes were safe, to the point where many people did not bother to lock their doors. Public schools 
were generally excellent, and their problems were things like talking in class and running in the halls." After a brief introduction on 'political correctness', terrorist and mass murderer Anders Behring Breivik's narrative of civilizational decline in his compendium 2083: A European Declaration of Independence opens by painting this romantic image of the 195 os as a time of harmony. Much energy has been devoted to exploring how to locate Breivik's islamophobia inside a broader extreme right discourse - and rightly so. However, from the emphasis put on islamophobia one could easily jump to the conclusion that Breivik thought that the reason we now grapple with bigger issues than kids talking in class is because of the impact of Muslim immigration to the West. Yet, his sprawling 1518-page compendium starts off by naming another culprit: the changed gender roles of Western societies. In the 195os, his narrative continues, '[m] ost men treated women like ladies, and most ladies devoted their time and effort to making good homes, rearing their children well and helping their communities through volunteer work. Children grew up in two-parent households, and the mother was there to meet the child when he came home from school. Entertainment was something the whole family could enjoy. What happened?'2

The answer that 2083 provides to its own rhetorical question, is that 'political correctness' or 'cultural Marxism' (which he uses as synonyms) have 'deconstructed' the traditional gender roles of Western society, thus shattering the natural structure of things - the consequences being low birth rates and a society vulnerable to a perceived Muslim 'invasion' and 'take-over.'

By analysing the anti-feminist and misogynistic narratives permeating Breivik's compendium, the aim of this paper is to approach the extreme right ideology of the Norwegian terrorist and mass-murderer as a form of non-egalitarian 'identity politics', and to show how this identity politics is connected to an overarching fascist conception of history, where late-modernity is seen as a form of exile from a glorious monocultural and patriarchal past. The article reframes and reformulates Nancy Fraser's concept of identity politics, considering the ideology of Breivik and his favourite writer, 'Fjordman', in relation to her theory of a 'politics of recognition.' ${ }^{3}$ One of the arguments put forth, is that Fraser's conceptual framework can be a useful heuristic device for analysing not only the feminist, socialist and 'deconstructive' movements which Fraser theorises, but also their opposites on the far right. In particular Fraser's distinction between a

Anders Behring Breivik, 2083: A European Declaration of Independence (2011), 12, https:// archive.org/details/2083_A_European_Declaration_of_Independence/page/n41.

2 Breivik, 2083, 12.

3 Nancy Fraser, 'From Redistribution to Recognition? Dilemmas of Justice in a "PostSocialist" Age,' New Left Review 212 (1995), no. 1. 
'politics of redistribution' and a 'politics of recognition' can be used to identify although after some significant reframing - how questions of identity - culture, 'race', gender - is at the 'core' of the dynamics of far-right extremist movements in general, and the vision of history expounded in 2083 in particular.

The main part of the article will be based on a discursive analysis of Breivik's compendium, which unavoidably entails an analysis of the essays which Fjordman wrote on feminism that made its way into the compendium that Breivik compiled. The reason for this, is the fact that Breivik used these essays without consent - as building blocks in his own narrative. A total of thirty-seven articles reproduced in 2083 were written by Fjordman, approximately $14,5 \%$ of the total word count. ${ }^{4}$

In order to understand the writings on gender and feminism that were written or reproduced in 2083, I will first discuss how Fraser's theories can be applied to the far right, then give an outline of the so-called 'counterjihad' discourse that Breivik subscribed to. Before I move on to investigate the misogynistic and anti-feminist narratives found in 2083, I will also seek to establish its ideology as a permeation of what Roger Griffin has labelled 'generic fascism', highlighting how Breivik's conception of history and anti-feminist narratives is entwined with a myth of civilisational decadence and rebirth.

With some notable exceptions, the misogynies that underpin Breivik's counterjihad ideology have perhaps not been recognised properly. However, Stephen J. Walton have contributed to the understanding of the issues of gender in his article 'Anti-feminism and Misogyny in Breivik's "Manifesto",'5 where he established how gender can be located at 'the analytical', 'the programmatic', and 'the autobiographical' levels of 2083. Another important contribution have been provided by Paul Jackson, who has analyzed Breivik's and Fjordman's fascist rhetoric, locating their take on gender issues as one part of their broader fascist discourse. ${ }^{6} \mathrm{~A}$ third valuable contribution has been provided by Mattias Gardell, who has argued along similar lines as this current article: that Breivik 'firmly stands in the fascist tradition ${ }^{7}$ and that anti-feminism is a key part of his

Paul Jackson, 'The License to Hate: Peder Jensen's Fascist Rhetoric in Anders Breivik's Manifesto "2083: A European Declaration of Independence", Democracy and Security 9, no. 3 (2013): 247-269, https://doi.org/10.108o/17419166.2013.802986.

Stephen J. Walton, 'Anti-Feminism and Misogyny in Breivik's “Manifesto"', NORA—Nordic Journal of Feminist and Gender Research 20 (2012): 4-11, https://doi.org/10.1080/08038740.2 011.650707 .

6 Jackson, 'The License to Hate.'

7 Mattias Gardell, 'Crusader Dreams: Oslo 22/7, Islamophobia, and the Quest for a Monocultural Europe,' Terrorism and Political Violence 26, no. 1 (2014), 129-155, https://doi. org/10.108o/o9546553.2014.849930. 
worldview. However, the added value of this current article, is that it delves far deeper into the anti-feminist narratives than Jackson and Gardell - who both treat it more briefly - at the same time as it locates the anti-feminism in the context of theories of both 'identity politics' and 'generic fascism' - perspectives lacking in Walton's article, which treats Breivik's misogynies in isolation.

\section{The Identity Politics of the Extreme Right}

Despite the lack of attention paid to the anti-feminist and misogynistic currents in Breivik's ideology, several scholars have called for more focus on gender and the far right. Cynthia Miller-Idriss has for instance drawn attention to how masculinity and nationalism is mutually reinforced in far-right ideologies: Miller-Idriss has shown how the masculine ideals of the far-right link contemporary European men to a myth of a heroic past, and that they highlight what it means to be a 'real man' within the national community, as well as demarcating borders which separate right-wing values from what is perceived as the hegemonic norms in society. 8

Also Cas Mudde has called for more attention to gender and the far-right, highlighting the 'deeply gendered' ${ }^{9}$ narratives of the far right. According to Mudde, far-right parties are not only predominantly Männerparteien. Far-right worldviews also ascribe a key role to allegedly 'natural differences' between the sexes. ${ }^{10}$ In this context, Mudde has pointed out how far-right narratives of the threatened national community allocate women a key - yet subordinated role in society: Since only women can give birth to children, and birth-rates are imagined to be of utmost importance in order to ensure the survival of the nation; the woman's role as mother and spouse becomes typically elevated into something heroic in the far-right narratives of civilisational decline.

Breivik's compendium displays the kind of masculine ideals identified by Miller-Idriss, as well as the narratives of falling birthrates as a symptom of national decadence and women as 'the womb of the nation', identified by Mudde. First off, his compendium is filled with allusions to the symbolic world of the Knights Templar that demonstrate Breivik's ideals of masculinity. To quote Gardell, the images of 'knights in shining armor, swords in hand, riding,

8 Cynthia Miller-Idris, 'Soldier, Sailor, Rebel, Rule-Breaker: Masculinity and the Body in the German Far Right,' Gender and Education 29, no. 2 (2017): 199-215, https://doi.org/10.108o/ 09540253.2016.1274381.

$9 \quad$ Cas Mudde, The Far Right Today (Oxford: Polity Press, 2019), 147.

10 Cas Mudde, Populist Radical Right Parties in Europe (Cambridge: Cambridge University Press, 2007); Hilde Coffé, 'Gender and the Radical Right', in Oxford Handbook of the Radical Right, ed. Jens Rydgren (Oxford: Oxford University Press, 2018). 
fighting, bursting forth'11 shows the kind of masculinity that Breivik wanted to restore through violence. Moreover, Breivik links his terrorist actions to a myth of a heroic, pan-European past, where figures like Charles Martel (686-741) and John III Sobieski (1629-1696), in Breivik's eyes, accomplished what he also aims at: Just in the nick of time, with the future of Europe at stake, these 'heroic' men fought off a 'Muslim invasion' by leading their peoples to victory in the Battle of Poitiers (732) and the Battle of Vienna (1683), respectively. ${ }^{12}$

Secondly, Breivik's compendium is filled with narratives of an ongoing 'genocide' caused by a combination of feminisation, low birth rates and Muslim immigration. Today, these narratives are widespread in the counterjihad ideology Breivik subscribed to, but also in the Identitarian Movement, and in different Alt-Right and neo-Nazi currents online. For instance, the narratives of feminisation and low birth rates was not only used to justify the terrorist attacks that Breivik conducted on 22 July 2011, killing seventy-seven people. Demographic anxiety was also a key ingredient in the manifesto uploaded online in relation to the Christchurch mosque shootings in New Zealand in March 2019, where fifty-one people were killed and forty-nine injured.

As such, knowledge of the specific anti-feminist and misogynistic narratives included and articulated in 2083 , can be important in order to understand the identity-based and gendered dynamics of far-right violence and extremism. As the research on lone-actor terrorism by Paul Gill, Tore Bjørgo and Cato Hemmingby shows, ideology is important in explaining how terrorists develop their justifications for violence. Yet, it also has some limitations, as other factors come in to play:13 As Hemmingby and Bjørgo have pointed out, both internal (such as psychological make-up, skills, access to weapons, manpower, funding, etc.) and external factors (such as unexpected events, counter-terrorism measures, local environments) play decisive parts in the terrorist target selection. Yet, ideology, Hemmingby and Bjørgo continue, still 'defines the overall objectives and the enemy picture, as well as the reasoning and moral reflections that constitute the basic fundament of the actor's rationality. 14

11 Gardell, 'Crusader Dreams,' 147.

12 Ibid.

13 See for instance: Paul Gill, Lone-Actor Terrorists: A Behavioral Analysis (London: Routledge, 2016); Paul Gill and Emily Corner, 'Lone-Actor Terrorist Target Choice,' Behavioral Sciences and the Law 34, 2016: 693-705, https://doi.org/10.1002/bsl.2268; Cato Hemmingby and Tore Bjørgo, 'Terrorist Target Selection: The Case of Anders Behring Breivik,' Perspectives on Terrorism 12, no. 6 (2018); Cato Hemmingby and Tore Bjørgo, The Dynamics of a Terrorist Targeting Process: Anders B. Breivik and the 22 July Attacks in Norway (London: Palgrave, 2015).

Hemmingby and Bjørgo, 'Terrorist Target Selection,' 164. 
As mentioned in the introduction, one of the arguments put forth in this article, is that Fraser's framework can be a useful heuristic device for analysing the identity-based dynamics of Breivik's ideology. Yet, as also mentioned, the application of her distinction between a 'politics of recognition' and a 'politics of redistribution' to the 'counterjihad' ideology of Breivik requires some reframing and reformulation. One of Fraser's aims in her seminal essay, "From Redistribution to Recognition? Dilemmas of Justice in a "Post-Socialist" Age', is to develop a 'critical theory of recognition.' ${ }^{15}$ In this context, Fraser discusses two forms of political conflict: The first one, is constituted by political struggles that centre on a demand for 'recognition of difference', i.e. the struggles of 'groups mobilized under the banners of nationality, ethnicity, "race", gender, and sexuality. ${ }^{16}$ The other one is made up of struggles which centre on a demand for socioeconomic redistribution, important terms being 'exploitation', 'interest', 'class', 'redistribution', etc. Writing in 1995, she observes that the first type of conflict, has become more important in recent times, to such an extent that 'cultural recognition displaces socioeconomic redistribution as the remedy for injustice and the goal of political struggle. ${ }^{17}$

Then, however, Fraser makes the point that we should not endorse or reject identity politics as such. The reason for this being that we need to distinguish between progressive and reactionary forms of identity politics: 'Instead of simply endorsing or rejecting all of identity politics simpliciter, we should see ourselves as presented with a new intellectual and practical task: that of developing a critical theory of recognition, one which identifies and defends only those versions of the cultural politics of difference that can be coherently combined with the social politics of equality.18

When applying Fraser's conceptual framework to right-wing extremism, it is important to have this in mind. To invert Karl Marx' famous phrase from his reworking of Hegelian dialectics, we may say that if Fraser's theory is standing with the right side up, we need to turn it on its head. ${ }^{19}$ While Fraser limits her theory to examining the dynamics of 'only those versions of the cultural politics of difference that can be coherently combined with the social politics of equality', ${ }^{20}$ thus ruling out 'nonegalitarian' forms of politics focused on nationalism, 'race', gender and sexuality, our aim is to do the exact opposite: to study

\footnotetext{
15 Fraser, 'From Redistribution to Recognition?', 69.

16 Ibid., 68.

17 Ibid.

18 Ibid., 69. My emphasis.

19 Karl Marx, Capital: A Critique of Political Economy. The Process of Capitalist Production, vol. 1 (New York: Cosimo Books, 2007), 25.

$20 \quad$ Fraser, 'From Redistribution to Recognition?', 69. My emphasis.
} 
those versions of identity politics that cannot be combined with the social politics of equality. As a result, the far-right ideology of Breivik can, inspired by Fraser's vocabulary, be labelled as a 'reactionary' (in terms of values) and 'non-egalitarian' form of identity politics, incompatible with the egalitarian ideals of the feminist, socialist and 'deconstructive' movements whose dynamics Fraser analyses. Breivik obviously does not strive towards a 'recognition of difference' in any egalitarian sense; rather, he wants, as we will see in the following, to 'recognise' difference in a hierarchical sense that privileges white, heterosexual European men and their perceived 'nature' and 'culture' at the expense of women and Muslims.

For the present study, Fraser's distinction can help us establish the discursive, cultural and ethnic dynamics of Breivik's ultranationalism as it is revealed in 2083. Although questions of culture and identity always will be entwined with material aspects - as Pierre Bourdieu and Jacques Rancière have taught us (from different angles) ${ }^{21}$ - Fraser can help us identify how politics of 'redistribution' and 'recognition' offer contrasting remedies for the grievances they address: Whereas the former aims at some form of political-economic restructuring, the latter aims at some sort of cultural or symbolic change. ${ }^{22}$

The point of reframing and reformulating this theory in the context of far-right extremism, is not that right-wing extremism is a legitimate attempt to undo injustices rooted in cultural misrecognition. The point is, rather, that even though they aren't, they are still perceived and articulated by extremists as a struggle against cultural injustice. Moreover, the point is neither that class or redistributive issues are irrelevant; the point is, rather, that the ideologies themselves do not recognise this relevance. To understand right-wing extremism properly, therefore, we need analytical tools that allow us to identify these dynamics - and, as I will try to show in the following, Fraser may perhaps provide us with some of these tools.

\section{The Counterjihadist Discourse}

Although Breivik is an unreliable narrator, both with regard to his own life and history as such, it is interesting to note the role he ascribes to precisely the kind of critical theory with which we interpret his ideology in this paper. Breivik is

Pierre Bourdieu, Distinction: A Social Critique of the Judgement of Taste (London: Routledge, 2010); Jacques Rancière, Proletarian Nights: The Workers' Dream in Nineteenth-Century France, translated by John Drury (London: Verso Books, 2012). 
not only opposed to the egalitarian ideals of critical theory, he blames them in part for the present state of decay he perceives the West of being in.

Earlier, we saw how Breivik painted a nostalgic picture of the 1950s. Without the slightest trace of irony, Breivik writes that if a family from the mid-twentieth century travelled in time and landed in the Western Europe of the 2ooos, they 'would head back to the 195 os as fast as they could, with a gripping horror story to tell.: ${ }^{23}$ One of the reasons for this 'horror' is that 'Western Europe has been conquered by the same force that earlier took over Russia, China, Germany and Italy':24 political correctness. 'Some people see it as a joke', he continues. 'it is not. It is deadly serious. ${ }^{25}$ The alleged seriousness stems from the fact that political correctness 'seeks to alter virtually all the rules, formal and informal, that govern relations among people and institutions. It wants to change behaviour, thought, even the words we use.... Whoever or whatever controls language also controls thought. Who dares to speak of "ladies" now?'26

However, in Breivik's world view political correctness is 'in fact' what he, following the American conservative pundit, William Sturgiss Lind, ${ }^{27}$ calls 'cultural Marxism' - that is, 'Marxism translated from economic into cultural terms. ${ }^{28}$ In this dubious narrative, the critical theory of the Frankfurt school plays a major role in the recent history of Europe. This 'cultural' brand of Marxism is a product of the Institute for Social Research in Frankfurt, and its ideology has radiated out from Germany, spreading its ideas all over the continent, and in the process taking 'over both political wings, left and right.'29 Hence, the perceived decline of Western societies can, in this narrative, be traced in part back to the establishment of the Institute for Social Research in 1923 .

Breivik claims the ideology championed by the 'cultural Marxist' has a handful of characteristics in common with classic, economic Marxism. According to the Norwegian mass murderer, they both share a vision of a society without hierarchies, and when they allegedly discover that hierarchies are a part of nature, he claims that they instead force their egalitarianism upon people.

\footnotetext{
23 Breivik, 2083, 12.

24 Ibid.

25 Ibid.

26 Ibid., 12-13.

27 Sindre Bangstad, Anders Breivik and the Rise of Islamophobia (London: Zed Books, 2014), 86; Toby Archer, 'Breivik's Mindset: The Counterjihad and the New Transatlantic AntMuslim Right,' in Extreme Right Wing Political Violence and Terrorism, ed. Max Taylor et al. (London: Bloomsbury, 2013), 172.

28 Breivik, 2083, 13.

29 Ibid., 14.
} 
Whereas economic Marxists seek to expropriate the property of the bourgeoisie, 'cultural Marxist', on the other hand, 'expropriate' the natural privileges of 'native European men', ${ }^{30}$ Breivik argues. These privileges are in turn handed out to groups he claims present themselves as 'victims': women, Muslims, minorities, homosexuals.

Already here we get an idea of how Fraser's theory of identity politics can be turned on its head, in order to understand this narrative where men are victims of cultural injustice brought about by feminism and cultural Marxism. We will explore these anti-feminist narratives in more detail below, but first we need to look closer at how Breivik imagines a link between cultural Marxism and Islam.

In Breivik's vision of history, 'cultural Marxism' also represents the source of a 'traitorous betrayal of Europe by its own leaders'. ${ }^{31}$ Entwined with his narrative of the feminist oppression of 'native European men', is the narrative of an ongoing 'Islamisation of Europe' through 'demographic warfare. ${ }^{32}$ This narrative is inspired by the so-called 'counterjihad' movement, what Breivik himself calls 'the Vienna School': Both the name of the 'school' and the title of the compendium - 2083 - is a reference to what this movement sees 'as the most important battle in European history: the Battle of Vienna in 1683 where the Islamic conquest of Western Europe was prevented by the Holy League, lead [sic] by John III Sobieski.'33 This movement advocates 'a new conservatism/nationalism' that he imagines can act 'an alternative to the left wing ... Frankfurt school of thought.'34 Elsewhere known as 'counterjihadism', its virtual hub are webpages including Gates of Vienna, and its central ideologues are writers/bloggers such as 'Bat Ye'or' (Gisèle Littman), Robert Spencer, 'Baron Bodissey' (Ned May), and 'Fjordman' (Peder Are Nøstvold Jensen).

The overall problem that Breivik wants to combat, is Muslim immigration to Europe, which, in his compendium, is presented as 'demographic warfare' and a conscious plan to replace 'the indigenous peoples of Europe. ${ }^{35}$ Drawing on Bat Ye'or's conspiracy theory of 'Eurabia' ${ }^{6}$ - as well as Fjordman's embrace of this theory in a series of essays on Gates of Vienna ${ }^{37}$ - Breivik believes that Norway and Europe are on the verge of being taken over by Muslims who,

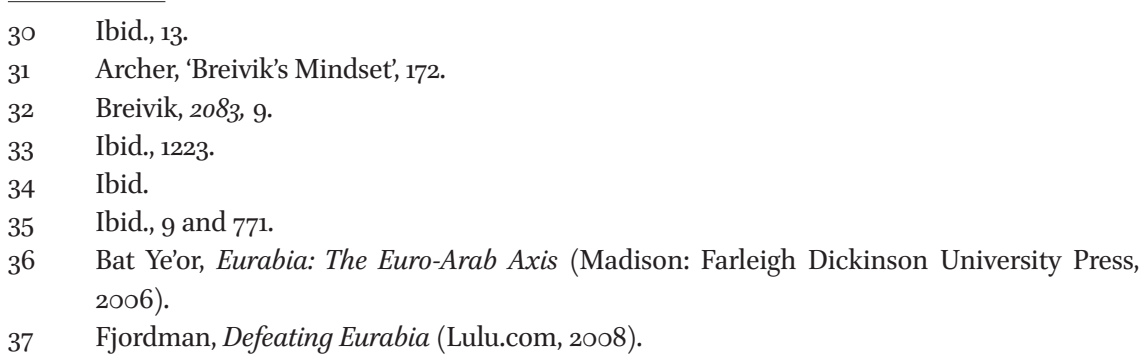


in collaboration with 'our own leaders', ${ }^{38}$ secretly plot to absorb Europe into a restored Islamic caliphate. ${ }^{39}$ This 'Islamisation' is part of an 1,400 year old war between Islam and Christianity. Like the Identitarian Movement, Breivik uses the aforementioned battles of Poitiers in 732 (where Charles Martel led a Frankish army that halted the advance of Islam in Europe) and Vienna in 1683 (where the King of Poland, John Sobieski, defeated the Turkish siege of Vienna) in order to construct a narrative of Islam as the eternal archenemy of European civilisation. ${ }^{40}$ The message is clear: Europe is once again under siege, and needs to rediscover its slumbering, masculine warrior instincts if it does not want to be annihilated by its eternal enemy. ${ }^{41}$

Yet, time is running out, in Breivik's conception of history: A secret plot to transform Europe into 'Eurabia' has accelerated and intensified since the oil crisis of 1973. In this narrative, the EU is portrayed as a hidden project where European elites work against their own people to destroy national sovereignty in Europe, thus laying the continent open for a Muslim take-over. ${ }^{42}$ In Eurabia: The Euro-Arab Axis, Bat Ye'or claims that her theory

[d] escribes Europe's evolution from a Judeo-Christian civilization, with important post-Enlightenment secular elements, into a post-Judeo-Christian civilization that is subservient to the ideology of jihad and the Islamic powers that propagate it. The new European civilization in the making can be called a 'civilization of dhimmitude.' The term dhimmitude comes from the Arabic word 'dhimmi'. It refers to subjugated, non-Muslim individuals or people that accept the restrictive and humiliating subordination to an ascendant Islamic power to avoid enslavement or death. The entire Muslim world as we know it today is a product of this 1,30o year old jihad dynamic, whereby once thriving non-Muslim majority civilizations have been reduced to a state of a dysfunctional dhimmitude.... Europe, as reflected by the institutions of the EU, has abandoned resistance for dhimmitude, and independence for integration with the Islamic world of North Africa and the Middle East. ${ }^{43}$

$38 \quad$ Breivik, 2083, 9 .

39 Bangstad, Anders Breivik and the Rise of Islamophobia, 145.

40 For the Identitarian Movement's use of these battles, see José Pedro Zúquete, The Identitarians: The Movement Against Globalism and Islam in Europe (Notre Dame, Indiana: University of Notre Dame Press,2018) 179 and 195.

41 Gardell, 'Crusader Dreams,' 147.

42 Jackson, 'The License to Hate,' 253.

43 Ye'or, Eurabia, 9-10. 
Breivik subscribes to this conspiracy theory that claims the existence of 'an overall vision for the transformation of Europe into a new geopolitical entity Eurabia. ${ }^{44}$ However, the main culprits, for Breivik, is not Muslims themselves, but the 'cultural Marxist', 'multiculturalist'. 'suicidal humanists' and 'feminist' elites $^{45}$ that in alleged collaboration with Muslims perform a 'genocide against the indigenous peoples of Europe by exposing them to more than 25 million Muslims. ${ }^{36}$ This is evident in a passage were Breivik radicalises Bat Ye'or's and Fjordman's theories, and writes of the need to take up arms as 'pre-emptive actions' and an act of 'self defence' in the name of 'the people':

We cannot allow our politically correct elites to sell us, their people, into Muslim slavery. The Multiculturalists and suicidal humanists have flooded Europe with criminals and individuals who are unwilling and unable to assimilate. As a result of these actions, more than 15 ooo Europeans have been murdered, more than 500 ooo European women have been raped and more than 5 million Europeans have been robbed, ravaged and physically or mentally abused since they opened the European gates in 1955-1970... They have institutionalised the genocide of European Christendom, our cultures and identities in a campaign to forcefully create a cultural Marxists Multicultural utopia. We are fighting to end this suffering, the suffering of the Europeans under cultural Marxism. We are fighting to end the murder, rape and humiliation of the European peoples. ${ }^{47}$

It is this conspiratorial narrative - that identifies Muslims and the multicultural 'elites' as an existential threat to the European people - that provided the 'rationale' for Breivik's terrorist actions on 22 July 2011. Only Breivik is accountable for these mass murders: He radicalised the counterjihad ideology, taking it far beyond the sources that inspired him, and devoted large parts of his compendium to advocating a violent, revolutionary uprising. If the narrative of an ongoing war, as well as the argument of the need to take up arms, was already provided by Fjordman, it was Breivik who weaponised it. ${ }^{48}$

\footnotetext{
44 Ibid., 10.

45 The categories are used as synonyms, often like this: 'political correctness/culturalMarxism/ multiculturalism.' Breivik, 2083, 338.

$46 \quad$ Ibid., 827 .

47 Ibid., 816.

48 For analyses of this connection, see Jackson, 'The License to Hate', and Vidar Enebakk, 'Fjordmans radikalisering,' in Høyreekstremisme: Ideer og bevegelser i Europa, ed. Øystein Sørensen et al. (Oslo: Dreyer forlag, 2012), 45-100.
} 
First of all, in an essay that Breivik reproduced in 2083, Fjordman provided the idea of an age-old battle between Islam and Europe:

This war by Islam against Europe, the West and indeed mankind has been going on for more than 1300 years. This is the third major Jihad, the third Islamic attempt to subdue the heartland of the West. Although I cannot prove this, I have a very strong feeling that this will also be the last attempt. There will be no fourth Jihad. Either Muslims will win this time, or Islam itself will be handed a defeat and a blow so powerful that it may never recover from it. This is perhaps the longest, continuous war in human history ${ }^{49}$

Moreover, Fjordman provided Breivik with the narrative - also reproduced in the compendium - of an ongoing European civil war, in which EU is betraying the European people:

In essence, the EU is formally surrendering an entire continent to Islam while destroying established national cultures, and is prepared to harass those who disagree with this policy. This constitutes the greatest organised betrayal in Western history, perhaps in human history, yet is hailed as a victory for 'tolerance.' . . . It would make sense to remember that all empires in history have been created through war. If the EU is an empire, this means that a war is being waged against somebody. And it is: A cultural and demographic war waged by mass immigration against native Europeans. Whereas empires are normally created by waging a war against other peoples, the EU is the first empire in history created by leaders allowing other peoples to wage a war against their own. ${ }^{50}$

Fjordman has distanced himself from Breivik's terrorist acts, but did stress the need to take up arms prior to 22 July 2011 - arguments that Breivik reproduced in $2083 .{ }^{51}$ In a dystopian essay, Fjordman for instance claimed that Western governments no longer protected their own citizens, and prophesied that Britain, Denmark or the Netherlands would be the first European countries to experience a full blown civil war due to Muslim Immigration: 'My advice to Westerners in general is to arm themselves immediately, first of all mentally with knowledge of the enemy and pride in their own culture and heritage, but also physically with guns and the skills to use them. Friedrich Nietzsche stated

49 Breivik, 2083, 339.

$50 \quad$ Ibid., 311.

$5^{1} \quad$ For a detailed analysis of these questions, see Enebakk, 'Fjordmans radikalisering.' 
in the nineteenth century that "God is dead." In the early twenty-first century it would be fair to say that "The State is dead," the replacement God in which we placed our trust after the other God died. ${ }^{52}$

In his projection into the future, Breivik wants to create a new European civilisation, based on what he perceives as the old 'heroic' and masculine values of a past European golden age. However, this doesn't mean that he wants to re-establish the past. Rather, Breivik wants, as historian Øystein Sørensen has pointed out, 'to retrieve the values from an imagined and idealized past in order to place them into a new context and to construct ... a new Europe.53 Again, the title of his compendium gives an idea of this futural dynamic: 2083 refers to the ending of 'the third' and crucial part of the 'European Civil War', when the existing regimes will be overthrown, and a new order will institute a 'European cultural renaissance ${ }^{54}$, based on past 'heroic' values. Constructing typical fascist binaries of 'decadence' and 'renaissance', Breivik emplotted Europeans into his historical narrative as an organic entity which has both an unchanging, synchronic 'eternal' aspect and a temporal, diachronic, historical dimension in which the drama of decay and rebirth is enacted through the triumph over the demonised 'enemies' of the people. Fjordman had written about the possibility of a 'second Renaissance', resulting from the 'life-and-death struggle with Islam, ${ }^{55}$ and Breivik embraced the idea: 'Western Europe has grown weak and decadent and will be completely annihilated culturally unless we succeed to implement a second European renaissance and reverse the damage done', he wrote in the compendium, adding that ' $[\mathrm{h}]$ istory has shown again and again that you cannot co-exist peacefully with Islam. ${ }^{56}$

Breivik's vision of an imminent war of 'counterjihad' against Islam to remove the existential threat faced by Norway/Europe and inaugurate a European rebirth clearly fits the definitional criteria proposed by Roger Griffin for conceptualising 'generic fascism. ${ }^{57}$ Following the practice of distinguishing between

$5^{2} \quad$ Breivik, 2083, 6oo.

53 Øystein Sørensen, 'Ideologi og galskap: Anders Behring Breiviks totalitære mentalitet,' in Høyreekstremisme: Ideer og bevegelser i Europa, ed. Øystein Sørensen et al. (Oslo: Dreyer forlag, 2012), 27. My translation.

54 Breivik, 2083, 1294.

55 Ibid., 337.

56 Ibid., 1352 .

57 This has also been pointed out by other scholars and by Griffin himself. See: Griffin, Fascism: An Introduction to Comparative Fascist Studies (Cambridge, UK; Medford, MA: Polity Press, 2018) 124; Jackson, 'The License to Hate,' 264; Gardell, 'Crusader Dreams,' 132-133; Øyvind Strømmen and Sigve Indregard, 'Den nye høyreekstremismen,' in Motgift: Akademisk respons på den nye høyreekstremismen, ed. Sigve Indregard (Oslo: Manifest and Flamme forlag, 2012), 34-35. 
upper-case 'Fascism' and lower-case 'fascism' - where the first is restricted to Mussolini's movement and regime, while the latter refers to a broader family of anti-democratic far-right movements - Griffin uses the term 'palingenetic ultranationalism' to refer to a 'core vision' of imminent - or eventual - rebirth of the nation, culture or people that permeate fascist ideologies. According to Griffin, fascism represents 'a revolutionary form of [ultra]nationalism': 'one that sets out to be a political, social and ethical revolution, welding the "people" into a dynamic national community under new elites infused with heroic values. The core myth that inspires this project is that only a populist, trans-class movement of purifying, cathartic national rebirth (palingenesis) can stem the tide of decadence. ${ }^{58}$ We find this vision of 'palingenesis' in Breivik's violent and fanatic ideology: His terrorist attacks were intended as propaganda by deed, with the goal of starting a process that he imagined would lead to a cathartic rebirth that would stem the tide of the perceived decadence. Showcasing a fascist rhetoric similar to the apocalyptic visions of a coming race war expressed in William Pierce's white supremacist novel The Turner Diaries, Breivik wrote that 'Europe will burn once more, and rivers from the blood of patriots, tyrants and traitors will flow through the streets. However, a new European cultural renaissance will be born from the ashes. Islam and Marxism will not prevail. 59

Yet, the extent to which this palingenesis is a misogynistic one, has perhaps not been properly recognised. Anti-feminism and misogyny is not peripheral to Breivik's palingenetic myth, but, as Stephen J. Walton has observed, ${ }^{60}$ lies at the heart of it. Breivik's 'European cultural renaissance' ${ }^{61}$ is not only going to resurrect a monocultural and homogenous society, but also patriarchy - something that is highlighted by the fact that the vision of how a 'new European cultural renaissance will be born from the ashes' is written under the heading 'Patriarchy will be re-implemented.' ${ }^{62}$ The misogynist and anti-feminist narratives that underpin his palingenetic vision and how these narratives can help us identify his 'generic fascist' ideology as a nonegalitarian and patriarchal form of 'identity politics' - will be explored in the rest of the paper.

\footnotetext{
$5^{8} \quad$ Roger Griffin, The Nature of Fascism (London: Routledge, 1993), xi.

59 Breivik, 2083, 1138.

6o Walton, 'Anti-Feminism and Misogyny in Breivik's "Manifesto", 5.

61 Breivik, 2083, 1294.

62 Ibid., 1138.
} 


\section{'Who Dares to Speak of "Ladies" Now?'}

Breivik perceives contemporary societies not only as undergoing Islamisation; he also perceives Western Europe as having become matriarchal societies. Like his islamophobic narratives, Breivik's misogynic ones are emplotted into his fascist conception of history, in which the alleged feminised (and Islamised) present is described as an estrangement from a glorious past dominated by white, European men. With reference to Breivik's anti-feminism, Mattias Gardell has pointed out that every anti-ism needs to elevate their enemy into a hegemonic position, in charge of an oppressive system, in order to position themselves as emancipatory. ${ }^{63}$ This is precisely what Breivik does - with both Islam and feminism. Drawing on a hackneyed myth of the 1950s as an time where men were allowed to be men, while women were 'ladies' (devoting 'their time and effort to making good homes'), 2083 presents an outline of history where the second wave of feminism in the 196os and 1970s tore the natural order between the sexes asunder.

In this regard, Breivik's compendium is characterised by an ambivalent form of sexism, where two forms of it co-exist, but occupy different roles in the conception of history: On one hand, by painting a mythic image of the 195os, it expresses a form of benevolent sexism, where women are seen as morally pure and physically weak. By contrast, with the rise of 'cultural Marxism' and feminism, women have allegedly become morally corrupt and politically powerful. As such, the compendium also expresses a form of hostile, antagonistic sexism that has become more widespread on the far right. According to Mudde, this form of sexism claims that women try to control men through both feminist ideology and sexual seduction. ${ }^{64}$ Such arguments are found in Breivik's compendium, where it is claimed that it is a 'highly underestimated'65 fact that women have used their erotic capital to manipulate men and gain societal hegemony. ${ }^{66}$

63 Gardell, 'Crusader Dreams,' 138-139.

64 Mudde, The Far Right Today, 15 o.

65 Breivik, 2083, 1177 .

66 In Male Fantasies, Klaus Theweleit provided a sustained psychoanalytic account of the simultaneous 'fear of women' (misogyny) and hatred of women (gynophobia) at the heart of right-wing extremism. Analysing the post World War One German Freikorps, Theweleit saw the fear and hatred of women as deeply bound up with a pathological fear of 'softness' associated with weakness and the corresponding need for boundaries, uniforms, orders and male hierarchy in order to restore 'order' and 'discipline'. See: Klaus Theweleit, Male Fantasies. Vol. 1, Women, Floods, Bodies, History (Minneapolis: University of Minnesota Press, 1987). 
However, the logic behind the argument of living in a matriarchal society, caused by the feminist revolution, can seem peculiar. Were we not, according to Fjordman, living as 'dhimmitudes' in a Europe under Islamic dominance? For Breivik, however, this dubious narrative makes sense, as he also believes that progressive 'cultural Marxists' are collaborating with reactionary Muslims in order to replace the population of Europe demographically and spiritually. According to Breivik, it is a 'fact' that ' $60-70 \%$ of all cultural Marxists/multiculturalists are women', something he believes can 'partly' explain 'why the gradual feminist revolution is directly linked to the implementation of multiculturalist doctrines. ${ }^{67}$

Despite this attempt at making feminism and jihadism compatible with each other, the tension remains. One of the reasons, is that within the counterjihad discourse a feminist styled rhetorical strategy is often deployed to defend women against Muslims. Paul Jackson has observed that in this context, white European men are presented as defenders of liberal values, such as women's rights - in stark contrast to the Muslim 'Other', which is portrayed as a threat to the modern, liberated woman. ${ }^{68}$ However, the feminist-style rhetoric of the counterjihad movement is accompanied by another rhetorical strategy, which can be read as an outright attack on the very same women's rights that they apparently defend. Using Fjordman as an example, Paul Jackson has argued that the Norwegian blogger's defence of women's rights in reality 'has nothing to do with feminism per se', but is a rhetorical strategy that is used to launch an 'attack on Islam as "non-European".'69

Mudde calls this rhetorical strategy for 'femonationalism': A strategy often deployed by the far right, where the language of women rights is mobilised as a weapon against immigration. ${ }^{70}$ This femonationalist rhetoric is found in 2083, where immigrants in general - and Muslims in particular - are portrayed as both a political and violently sexualised threat to women. ${ }^{71}$ One example of such femonationalist rhetoric, is found in Breivik's reproduction of Fjordman's 'The Failure of Western Feminism'. In his reproduction of the essay, Breivik used a quote from the American poet Robert Frost as an epigraph: 'Don't ever take a fence down until you know why it was put up. ${ }^{72}$ With this simple

\footnotetext{
67 Breivik, 2083, 1177 .

68 Jackson, 'The License to Hate,' 259.

69 Ibid., 259-26o.

70 Mudde, The Far Right Today, 152.

$71 \quad$ For instance, immigrants are repeatedly presented as rapists. 'Rape' is mentioned 71 times in the compendium, 'raped' 47 , 'raping' 7 times, 'rapes' 27 , while rapist/rapists is mentioned 6 times. See also: Jackson, 'The License to Hate', 257, and Breivik, 2083, 347. 
heading, Breivik highlighted what he found important in the text: The fence that has been taken down is Western patriarchy and masculinity, the ones who have taken it down are women - and it was originally put up to protect the very same women from 'external aggression by men.' ${ }^{73}$

According to the vision of history presented in 2083 , the attacks on male privilege that have been conducted in the name of postwar feminism have had several damaging effects. We now see a 'massive wave of violence and especially rapes in Western cities, ${ }^{\prime 4}$ it claims - and the texts compiled in Breivik's compendium urge us to recognise this alleged wave as 'warfare against whites.' ${ }^{75}$ Violence and rapes are, in other words, part of a cultural and religious war between Europe and Islam, and women have 'to some extent brought this upon themselves', Fjordman argues in one of the reproduced texts. By weakening the authority of European masculinity, they have left the continent open to a Muslim invasion and takeover:

The truth is that any nation is always protected from external aggression by the men. The women can play a supporting role in this, but never more than that. For all the talk about 'girl power' and 'women kicking ass' which you see on movies these days, if the men of your 'tribe' are too weak or demoralised to protect you, you will be enslaved and crushed by the men from other 'tribes' before you can say 'Vagina Monologues'. Which means that if you break down men's masculinity, their willingness and ability to defend themselves and their families, you destroy the country. That's exactly what Western women have done for the last forty years. So why are you surprised about the results? As you said, you can't fool Mother Nature. Well, you have tried to fool her for a long time, and you are now paying the price for this. ${ }^{76}$

This reasoning echoes blogposts Fjordman wrote in 2006 and 2007, both reproduced in 2083 , with the telling titles 'How the Feminists' "War against Boys" Paved the Way for Islam' and 'How Feminism Leads to the Oppression of Women'. In the former, feminism was blamed for both the alleged collapse of Western civilization and for the failure of European people to recognize that their very existence is threatened: 'The male protective instinct doesn't take action because Scandinavian women have worked tirelessly to eradicate it,

\begin{tabular}{ll}
\hline 73 & Ibid. \\
74 & Ibid. \\
75 & Ibid. \\
76 & Ibid.
\end{tabular}


together with everything else that smacks of traditional masculinity. Because of this, feminism has greatly weakened Scandinavia, and perhaps Western civilisation as whole $[\mathrm{sic}] .{ }^{77}$ The overall outcome of this, is that '[r]adical feminism ... leads to oppression of women', since men have become 'fed-up' with the demonization of masculinity:

If Western men are pigs and 'just like the Taliban' no matter what we do, why bother? Western women will then be squashed by more aggressive men from other cultures, which is exactly what is happening in Western Europe now. The irony is that when women launched the Second Wave of Feminism in the 196os and 7os, they were reasonably safe and, in my view, not very oppressed. When the long-term effects of feminism finally set in, Western women may very well end up being genuinely oppressed under the boot of Islam. ${ }^{78}$

However, feminism has not only weakened Western civilisation culturally, but also demographically in Fjordman's account of the recent history of the West: ${ }^{79}$ They have torn the traditional family structure asunder, and installed feminist policies that have resulted in 'skyrocketing divorce rates and plummeting birth rates', ${ }^{\prime 0}$ making the continent vulnerable to a Muslim 'take-over'. According to Fjordman, the combination of secularisation, social security programs that are 'dangerously generous', ${ }^{81}$ birth control measures, such as abortion and contraceptive pills, and working women has led to a situation where Europe have 'chosen to disappear from the face of the earth. ${ }^{\text {' } 22}$

This brief outline of Fjordman's evaluation of the consequences of feminism clearly corroborates Jackson's claim that his defence of women's rights on closer inspection - reveals itself as having nothing to do with feminism as such, but is following the femonationalist logic of attacking Islam as not belonging in Europe. To use Fraser's terminology, there is nothing that indicates that he wants to do something with the gender-specific modes of exploitation that women suffer from. In other words: there is nothing to indicate that Fjordman wants any redistributive means in order to remedy economic injustices women may suffer. Rather, when he writes, in an essay entitled 'What

\begin{tabular}{ll}
\hline 77 & Ibid., 345. \\
78 & Ibid., 355. \\
79 & Ibid., 351. \\
8 o & Ibid., 354. \\
81 & Ibid., 357. \\
82 & Ibid.
\end{tabular}


is the Cause of Low Birth Rates?', that he is 'not against' working women, he is conducting a performative contradiction. In the sentence before, he writes that the 'main problem is the working women', 83 while in the next section where he actually proposes redistributive policies (prerogative rights for families with more than three children to live in state-initiated housing units), they are explicitly designed to keep mothers from both filing a divorce and from working full time.

\section{Demographic Anxiety}

The manifesto written by the self-proclaimed 'eco-fascist' terrorist behind the Christchurch mosque shootings in New Zealand in 2019 highlights the role of demographic anxiety in right-wing extremist discourse. The centrality of demographics and fertility to his analysis of 'white' racial decadence is made clear by the fact that Tarrant repeats 'It's the birthrates' 84 three times in the opening paragraphs of his manifesto. Its title - The Great Replacement is a reference to a conspiracy theory often disseminated by the Europe-wide Identitarian Movement, structurally similar to the Eurabia one: ${ }^{85}$ It claims that White Westerners are systematically being replaced by coloured and non-European people, especially Muslims, through mass migration and demographic growth. ${ }^{86}$ Using typical fascist biological metaphors of 'decay' and 'death', Tarrant writes that unless the birth-rates change, 'the European people' will be 'spiralling into decay and eventual death', even 'if we were to deport all Non-Europeans from our lands tomorrow'. Using a similar rhetoric to Breivik's, Tarrant claims that the West are experiencing 'an invasion on a level never seen before in history.' Furthermore, he sees this as an intended 'assault on the European people that, if not combated, will ultimately result in the complete racial and cultural replacement of the European people. ${ }^{87}$

\footnotetext{
$83 \quad$ Ibid., 358 .

84 Brenton Tarrant, The Great Replacement (2019), 3, available at https://img-prod.ilfoglio.it/ userUpload/The_Great_Replacementconvertito.pdf.

85 Zúquete, The Identitarians, $146 \mathrm{f}$.

86 Andreas Önnerfors “The Great Replacement”: Decoding the Christchurch Terrorist Manifesto,' Radicalrightanalysis.com, March 18, 2019, accessed April 4, 2019, https://www. radicalrightanalysis.com/2019/o3/18/the-great-replacement-decoding-the-christchurchterrorist-manifesto/; Renaud Camus, Le Grand Remplacement (Chez l'auteur, 2011). 
However, as Breivik's compendium testifies, the stress on the need to 'ensure sustainable indigenous fertility rates' 88 was also a central part of the Eurabia conspiracy theory that Breivik subscribed to - and here women and feminism were blamed for the development. In an essay that Breivik reproduced in 2083, Fjordman claimed that ' $[\mathrm{t}]$ he latest wave of radical feminism has severely wounded the family structure of the Western world', since it 'is impossible to raise the birth rates to replacement level before women are valued for raising children, and before men and women are willing to marry in the first place.'89 Using an apocalyptic rhetoric, Fjordman drew parallels between the demographic development in the West and the Black Death:

Demographics is destiny. Never in recorded history have prosperous and peaceful nations chosen to disappear from the face of the earth. Yet that is what the Europeans have chosen to do. Back in 1348 Europe suffered the Black Death, a combination of bubonic plague and likely a form of mad cow disease, observes American Enterprise Institute scholar Ben Wattenberg. 'The plague reduced the estimated European population by about a third. In the next 50 years, Europe's population will relive - in slow motion - that plague demography, losing about a fifth of its population by 2050 and more as the decades roll on. ${ }^{90}$

As his endorsement of this view of history indicates, there is nothing that indicates that Breivik perceives women as suffering from any injustices related to gender as a cultural-valuational differentiation. Rather, he makes the opposite claim: that men suffer from cultural misrecognition, that feminism have made masculinity into what Fraser would call a 'disrespected identity', something that will be explored in more detail in the last section.

\section{Narrative of Victimhood, Narrative of Entitlement}

As Stephen J. Walton has observed, there is a dual rhetoric involved in the writings on feminism and gender either written or reproduced by Breivik in the compendium: He portrays himself as a victim of feminism - at the same time as he criticises feminism for playing out a narrative of victimhood. ${ }^{91}$ On one

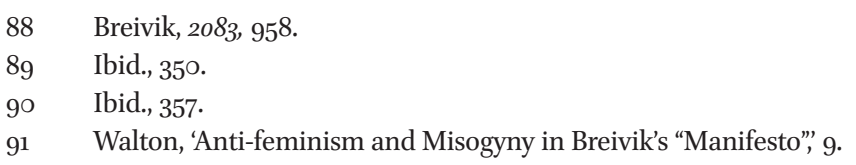


hand, Breivik attacks the 'cultural Marxist' and feminist for portraying themselves as victims, and for only showing solidarity with other 'victim groups'. For instance, he reproduces the claim put forward by Fjordman that Western feminism has 'strayed away into extremism' 92 and 'cultivated a culture of victimhood in the West, where you gain political power through your status in the victim hierarchy. ${ }^{93}$ Again reproducing an essay by Fjordman, Breivik claims that this culture of victimhood is now being exploited by the Muslim 'intruders':

When Muslims, who above all else like to present themselves as victims, enter Western nations, they find that much of their work has already been done for them. They can use a pre-established tradition of claiming to be victims, demanding state intervention and maybe quotas to address this, as well as a complete re-writing of history and public campaigns against bigotry and hate speech. Western feminists have thus paved the way for the forces that will dismantle Western feminism, and end up in bed, sometimes quite literally, with the people who want to enslave them. ${ }^{94}$

On the other hand, however, Breivik presents himself - and white European men in general - as victims of feminism..$^{95}$ For instance, he reproduces Fjordman's claim that boys today 'grow up in an atmosphere where masculinity is demonised'96 and that the school systems views them as 'deficient'. He even reproduces Fjordman's dubbing of the West as 'the Fatherless Civilisation' 97 - a society in which traditional male values are 'ridiculed' and 'demonised', where men are supposed to be feminine and have a 'vague' 98 gender status, and where paternal authority is knocked off the perch and replaced by a feminised public upbringing in kindergartens and schools.

This hyperbolic notion of the fatherless civilisation is emblematic for Breivik's image of the feminised West: Just as in Alfred Hitchcock's movies The Birds and Psycho, 2083 portrays a society without a paternal super-ego as one characterised by madness, unbound sexuality and swarming attacks from dark forces: '[...] the current situation isn't sustainable', he claims via an essay by Fjordman: 'The absence of fatherhood has created a society full of social

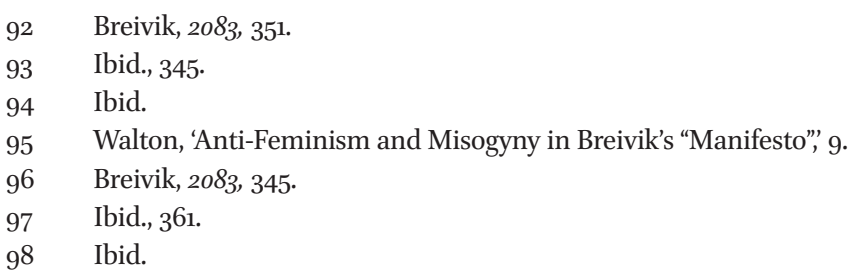


pathologies, and the lack of male self-confidence has made us easy prey for our enemies. If the West is to survive, we need to reassert a healthy dose of male authority. In order to do so we need to roll back the welfare state. Perhaps we need to roll back some of the excesses of Western feminism, too.'99

Similar visions of history, which laments society's 'fatherless' gender fluidity and 'gynecocracy', have been promulgated by some of the key thinkers of the European New Right, such as Alain de Benoist and Julius Evola. ${ }^{100}$ In Manni Crone's words, both de Benoist and Evola see modernity as 'a grievous decline from a glorious past, where heroic male virility - in tandem with a Spartan warrior ethos - reigned supreme, to a feminised world of soft consumption and endless palaver.'101 This philosophy of history is in line with Breivik's and Fjordman's vision of the gradual decadence of Western societies. Fjordman makes no reference to him, but it's not unlikely that he was influenced by Danish historian Henrik Jensen and his book Det faderløse samfund [The Fatherless Society $]^{102}$ when developing his own notion of the fatherless West. Like Fjordman, Jensen views late modernity as feminised, a society where the subject is relieved of any authority and duty, and instead encouraged to pursue individual self-realisation. ${ }^{103}$ Whereas 'the father', for both Henrik Jensen and Fjordman, becomes a metaphor for an hierarchical culture of duty, where the subject need to meet the demands of God, parents, society, and tradition, the 'mother' becomes a metaphor for the opposite: a disintegrating, horizontal, socially 'flattening' tendency, which places society into a perpetual adolescence and identity crisis, where 'mothers imitate their daughters, not vice versa.' ${ }^{104}$ Jensen views the narrative of victimhood as a result of the feminised culture of late modernity: in it, the individual no longer thinks that s/he needs to answer any societal 'duties', rather society needs to conform to the 'rights' of the individual. ${ }^{105}$

Ironically, the narrative of the 'Fatherless Civilisation' portrays men as victims of rampant feminism, at the same time as it attacks feminists for playing the victim card. In Breivik's compendium, for instance, the narrative of victimhood and loss of paternal authority is not only played out at the political

\footnotetext{
$99 \quad$ Ibid., 363.

100 Manni Crone, 'Restoring Masculinity to Dominance: Patriarchal Order or Homoerotic Virility?' paper presented at the conference 'Det yderste højres idéhistorie', Aarhus University, Denmark, February 2020. Crone, 'Restoring Masculinity to Dominance.' Henrik Jensen, Det faderløse samfund (København: People's Press, 2006). Ole Jacob Madsen, Den terapeutiske kultur (Oslo: Universitetsforlaget, 2010), 74.

$104 \quad$ Breivik, 2083, 363.
105 Madsen, Den terapeutiske kultur, 74-75.
} 
and historical level, but also in the parts where Breivik writes about his own upbringing. ${ }^{106} \mathrm{He}$ writes that he has had 'a privileged upbringing with responsible and intelligent people around me', but, growing up without a father around, he still cannot 'approve of the super-liberal, matriarchal upbringing though as it completely lacked discipline and has contributed to feminise me to a certain degree.' 107

These narratives of male victimhood and the 'fatherless' West is perhaps the most striking manifestations of how Breivik's right-wing extremism is deceptively articulated as a struggle against cultural injustice. It is, of course, not a legitimate articulation of identity politics. On the contrary. This ideology is not striving towards any egalitarian 'recognition of difference' in Fraser's sense, but what Norwegian philosopher Arne Johan Vetlesen has called a 'narrative of entitlement', ${ }^{108}$ where men, like Breivik, wrongly think that they are only claiming what is rightly theirs, not recognising that they ascribe privileges to themselves that they deny others, such as women, homosexuals and Muslims. However, Fraser's theories can still be used to identify these 'cultural' and identity-based dynamics, which suspend every question of class, exploitation and redistribution, and articulates a politics in purely cultural and identity-based terms. This point is corroborated by the fact that Breivik labels economic policies as an area 'not covered by the school of thought' that he subscribes to. While he has a wide range of policies to control reproduction and cultural production and consummation, Breivik refrains from outlining 'a description of a clear economical platform.'109

\section{The Motherless Civilisation}

Breivik built upon Fjordman's essays on feminism and postwar history when he tried to articulate this non-egalitarian identity politics and anti-feminist vision of history. Yet, Fjordman's writings could only take him up to a certain point. As with his conspiracy theories of a Muslim takeover of Europe, Breivik's misogynist identity politics went further than his sources of inspiration. As a solution to the alleged 'breakdown of sexual moral in Western Europe',110

\footnotetext{
106 Walton, 'Anti-Feminism and Misogyny in Breivik's “Manifesto”, 8.

107 Breivik, 2083, 1387.

108 Arne Johan Vetlesen, 'Narratives of Entitlement,' in Moral Evil in Practical Ethics, eds. Shlomit Harrosh and Roger Crisp (London: Routledge, 2018), 80-102.

109 Breivik, 2083, 1234.

110 Ibid., 1170.
} 
which he imagines 'will cause all social structures to completely deteriorate',111 Breivik for instance proposes to restrict women's rights and freedom of speech, and implement a new 'sexual ethics for all'112 after the violent seizure of political power that he envisions in the future. These ethics will be implemented 'through the strict regulation of media,'113 and a ban on cultural products that promote a liberal lifestyle.

More disturbingly, however, was the fact that he not only saw the present as a fatherless civilisation, but also envisioned a future motherless civilisation. First, he fantasised about restricting women's rights in order 'to allow the state to play an essential role in national reproduction', and establish a 'network of surrogacy facilities in low cost countries.'114 By injecting already fertilised eggs into the host mother, the child would be genetically European, despite the ethnic identity of the surrogate. ${ }^{115}$ In the long run, however, he envisioned a development where 'advanced incubator machines/artificial wombs'116 will make women superfluous altogether.

This confrontation with maternal authority can be read on different levels in Breivik's compendium. ${ }^{117}$ On a more personal level, Breivik claims that his sister and mother lack sexual morals, something he feels has 'shamed' his family, "[a] family that was broken in the first place due to secondary effects of the feministic/sexual revolution.' ${ }^{118}$ On a collective level, however, his fascist vision of a future civilisational rebirth is not only meant to resurrect a monocultural and homogenic society, but also reverse the effects of the sexual revolution and feminism, and restore patriarchy. ${ }^{119}$ His terrorist attacks were intended to bring about a civil war that he imagined would put an end to gender equality and 'the Islamic colonization ... of Western Europe'. ${ }^{120}$ In a revealing passage, he wrote that terrorists who want to follow his path have to 'familiarise ... with the concept of killing women, even very attractive women', since 'approximately $60-70 \%$ of all cultural Marxists or suicidal humanists are female.'121

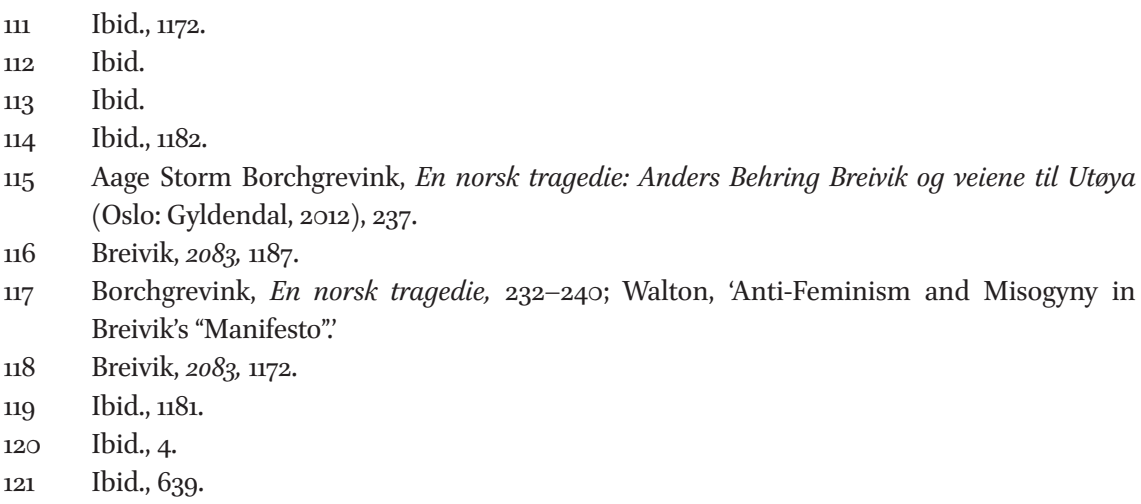


But not only very attractive, young women were to be the killed. Inspired by the beheadings of al-Qaida, Breivik wanted to perform the kind of symbolic act with which IsIS would later send shock waves through the world. Yet, he added his own misogynist twist to it: He wanted to capture the former social democratic prime minister, Gro Harlem Brundtland, who attended Utøya on 22 July 2011. Brundtland was the first female prime minister of Norway and is widely regarded as 'the mother of the nation'. Bent on restoring masculinity to dominance and reverse the effects of egalitarianism, Breivik fantasized to decapitate Brundtland and then upload the footage online.

\section{Concluding Remarks}

Our analysis has shown how Breivik's counterjihadism fits the template of what Roger Griffin has labelled 'generic fascism, ${ }^{122}$ though in a way that reflects profound political, economic, and particularly cultural changes separating the inter-war situation and the contemporary situation that Breivik wished to transform. ${ }^{123}$ Yet underpinning Breivik's identity-oriented and in many respects highly idiosyncratic brand of 'counterjihadism' lies the familiar Manichean view of history common to all fascisms where the pure and the corrupted are pitted against each other, and where the West is seen as spiralling into decay. Breivik's diagnosis of contemporary Western societies, is characterised by a sense of facing an 'overwhelming crisis beyond the reach of any traditional solutions.' ${ }^{124}$ In this context, his terrorist attacks were meant to be received as propaganda by deed, with the goal of kick-starting a process of regeneration that he imagined eventually would lead to a collective cathartic rebirth able to save Europe from the alleged decadence caused by feminism and (Muslim) immigration.

The extent to which this ultranationalist palingenesis is a misogynistic one has perhaps not been properly recognised by commentators. Anti-feminism and misogyny are not peripheral to Breivik's ideology, but lie at the centre of it. The victim of the alleged Manichean battle between good and evil, are not only the present national and European community, but also the European men, deliberated and feminised by cultural Marxism and feminism. As such, his imagined 'conservative revolution' is not only going to resurrect a societal order without Muslims and 'cultural Marxists'; it is also supposed to reinstall

\footnotetext{
122 Griffin, The Nature of Fascism, xi.

123 Ibid..

124 Robert O. Paxton, The Anatomy of Fascism (New York: Knopf, 2004), 40.
} 
patriarchy and gender difference as the precondition to demographic and cultural rebirth.

One conclusion to be drawn from the above analysis is that knowledge of the specific brand of anti-feminist and misogynistic identity politics included and articulated in 2083, can be important in order to understand the identity-based dynamics of far-right violence and extremism in general. Cas Mudde has pointed out that although traditional gender roles and misogyny 'are often mentioned as reasons for why women feel less attracted by the far right, they are less often mentioned, and rarely elaborated upon, as reasons why men are more attracted. ${ }^{\prime 25}$ Yet, as Mudde suggests, these kinds of non-egalitarian identity politics may explain why disgruntled men with a feeling of being disenfranchised and emasculated become attracted to the far right, since it offers a type of politics that 'makes sense' of - and claims to have 'solutions' for - their socio-sexual grievances.

That knowledge of the anti-feminist identity politics of the far right is important, is underlined by the fact that the issues addressed in this article were not only central in Breivik's choice of targets for his terrorist actions in 2011. It was also at the core of the narrative that the Christchurch terrorist used to justify murdering fifty-one people in 2019. Yet, whereas Breivik directed his terrorist attacks against the 'traitors' and 'enemies within', the Christchurch shooter attacked mosques based on an equally perverse logic: that due to low birthrates, time was running out if 'white people' wanted to avoid 'extinction'. This reasoning was based on a similar misogynistic narrative as the one identified in 2083 - a narrative that states that 'the destruction of the traditional family unit'126 has laid the West open for a foreign 'invasion'. Echoing Breivik's gynophobic fantasies, Tarrant urged 'Men of the West' to become 'men once more'. In this context, far-right anti-feminism not only presented a 'solution' for the disenfranchised men, but cast them in the role as heroic saviors of the West. 'Strong men do not get ethnically replaced,' Tarrant claimed, 'strong men do not allow their culture to degrade, strong men do not allow their people to die. Weak men have created this situation and strong men are needed to fix it.'127

125 Mudde, The Far Right Today, 159.

126 Tarrant, The Great Replacement, 5.

127 Ibid., 19, 3 o. 